\begin{tabular}{cc} 
bentham open & The Open Automation and Control \\
Systems Journal & Content list available at: www.benthamopen.com/TOAUTOCJ/ \\
DOI: $10.2174 / 1874444301608010103$ & $\substack{\text { The Open } \\
\text { Automation and Control } \\
\text { Systems lournal }}$ \\
\hline
\end{tabular}

RETRACTION

\title{
Retraction Notice: Parameter Estimation of Fractional Low Order Time-frequency Autoregressive Based on Infinite Variance Analysis
}

Cao Ying*, Yuan Qingshan and Zeng Lili

Northeast Petroleum University, Daqing, Heilongjiang 066004, China

Abstract: As per Bentham Open's policy, the following article has been retracted at the request of the Editor-in-Chief and authors of the journal 'The Open Automation and Control Systems Journal'.

Title: "Parameter Estimation of Fractional Low Order Time-frequency Autoregressive Based on Infinite Variance Analysis"

Authors: Cao Ying*, Yuan Qingshan and Zeng Lili

\section{Bentham Open Disclaimer}

It is a condition of publication that manuscripts submitted to this journal have not been published and will not be simultaneously submitted or published elsewhere. Furthermore, any data, illustration, structure or table that has been published elsewhere must be reported, and copyright permission for reproduction must be obtained. Plagiarism is strictly forbidden, and by submitting the article for publication the authors agree that the publishers have the legal right to take appropriate action against the authors, if plagiarism or fabricated information is discovered.

\section{REFERENCE}

[1] C. Ying, Y. Qingshan, and Z. Lili, "Parameter estimation of fractional low order time-frequency autoregressive based on infinite variance analysis", Open Autom. Control Syst. J., vol. 7, pp. 2083-2089, 2015.

(c) Ying et al.; Licensee Bentham Open.

This is an open access article licensed under the terms of the Creative Commons Attribution-Non-Commercial 4.0 International Public License (CC BY-NC 4.0) (https://creativecommons.org/licenses/by-nc/4.0/legalcode), which permits unrestricted, non-commercial use, distribution and reproduction in any medium, provided the work is properly cited.

\footnotetext{
* Address correspondence to this author at the Northeast Petroleum University, Daqing, Heilongiiang 066004, China; Tel: 13333305201; E-mail: Caoying0909@163.com
} 